ELORE (ISSN 1456-3010), vol. 19 - 2/2012.

Julkaisija: Suomen Kansantietouden Tutkijain Seura ry.

[http://www.elore.fi/arkisto/2_12/hakkinen.pdf]

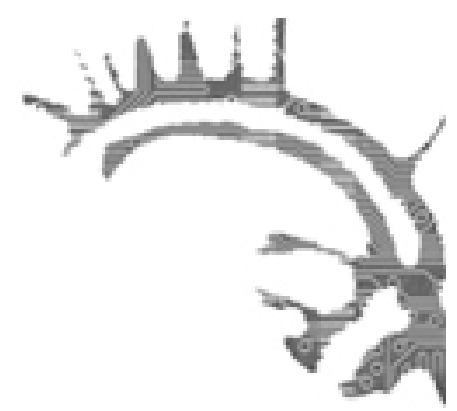

KIRJA-ARVIO

\title{
NÄKÖKULMIA PAKOLAISUUDEN, PAIKAN JA IDENTITEETIN TUTKIMUKSEEN
}

MALKKI, LIISA 2012: Kulttuuri, paikka ja muuttoliike. Toimittanut Laura Huttunen. Tampere: Vastapaino. 283 sivua.

\section{Anne Häkkinen}

Käsissäni oleva teos Kulttuuri, paikka ja muuttoliike puolustaa paikkaansa suomennettujen tieteellisten kokoomateosten joukossa. Kirjaan on koottu kuusi Liisa Malkin artikkelia, jotka ovat ilmestyneet vuosina 1992-2007 tieteellisissä aikakauslehdissä ja artikkelikokoelmissa. Suomalaissyntyinen, Stanfordin yliopistossa Yhdysvalloissa työskentelevä antropologi Liisa Malkki on käsitellyt tuotannossaan erityisesti pakolaisuuteen ja globaaliin liikkuvuuteen kytkeytyviä teemoja. Näiden teemojen ympärille rakentuvat myös käsillä olevan kirjan artikkelit. Artikkeleissa Malkki muun muassa analysoi sekä populaareja puhetapoja pakolaisuudesta että akateemisen tutkimuksen tapaa määritellä kohteitaan. Kirjoituksissa tarkastellaan kriittisesti esimerkiksi sitä, kuinka hallinto, journalismi sekä humanitaariset järjestöt määrittelevät ja kohtaavat "kohteensa". Kirjalle valittu suomenkielinen nimi kuvaa varsin osuvasti sen sisältöä: useat teoksen artikkeleista keskustelevat kulttuurin, identiteetin ja paikan välisistä suhteista nykyisessä maailmassa, jota leimaa liikkuvuus yli valtioiden rajojen.

Teoksen artikkelit pohjautuvat Malkin väitöskirjan Purity and Exile: Violence, Memory and National Cosmology among Hutu Refugees in Tanzania (1995) etnografiseen aineistoon. Vaikka kirjoitukset ammentavat samasta empiirisestä aineistosta, kukin artikkeli 
lähestyy aihetta oman erityiskysymyksensä kautta. Etnografisesta tutkimusotteesta kiinnostuneille lukijoille kirjan artikkeleilla on annettavaa näin ollen myös metodologisesta näkökulmasta. Artikkelien lisäksi teos sisältää kirjan toimittaneen sosiaaliantropologian professori Laura Huttusen kirjoittaman johdannon. Johdanto-osuus esittelee tekstien kirjoittajan Liisa Malkin ja artikkelit lyhyesti, avaa lukijalle toimituksen tekemiä käännösvalintoja sekä nivoo yhteen kirjoituksissa toisiinsa limittyvät ja kantavat teemat. Näitä teemoja esittelen seuraavaksi ottamalla kolme Malkin artikkelia lähemmän tarkastelun kohteeksi.

\section{Pakolaiset Ja asioiden kansallinen JÄrJestys}

Kirjan ensimmäisessä artikkelissa "Kansallista maantiedettä: Juuret, alueet ja identiteetit" Malkki purkaa usein itsestään selvänä pidettyä ajatusta ihmisten identiteettien ja maantieteellisen paikan välisestä suhteesta. Tämä oletettu suhde näkyy esimerkiksi siinä, miten ihmiset luokitellaan tai kuinka he identifioituvat kotimaahan, kulttuuriin ja alkuperään, ja puhuvat esimerkiksi juuristaan. Malkki esittää, että toimintaamme ohjaa monessa asiassa luonnollistunut tapa jäsentää maailmaa kansakuntien kautta; pidämme itsestään selvänä sitä, että maailma on jakaantunut selvärajaisiin kansallisiin yksiköihin ja kutakin yksikköä vastaa tietty maa-alue, kieli, kulttuuri ja ihmisryhmä. Tätä ilmiötä hän kutsuu asioiden kansalliseksi järjestykseksi.

Malkin mukaan asioiden kansalliseen järjestykseen kytkeytyy taipumus ajatella ihmisiä ja asioita paikkaan kiinnittyviksi ja liikkumattomiksi. Hän käyttää ilmiöstä nimitystä liikkumattomuuden metafysiikka. Malkki esittää, että niin tutkimuksessa kuin arkiajattelussa pidämme paikallaan pysymistä luonnollisena kun taas liike vaatii selityksiä, sillä miellämme ihmisten ja kulttuurien saavan identiteettinsä niiden kiinnittyessä tiettyyn paikkaan. Kuten Malkki kirjoittaa: "Usein rajojen ja niiden ylittämisen saama huomio ei liity niinkään tiettyjen ihmisryhmien fyysiseen liikkumiseen vaan siihen, että ihmiset, tavarat ja kulttuurituotteet joutuvat 'kulttuurisesti väärään paikkaan’” (s. 26). Asioiden liikkumattomuuteen nojautuvan ajattelutavan seurauksena on kuitenkin paikasta toiseen liikkumisen patologisointi, kuten pakolaisten tapauksessa.

Pakolaisten patologisointi näkyy Malkin mukaan muun muassa siinä, miten heitä on määritelty toisen maailmansodan aikaisissa tutkimuksissa. Niissä pakolaisten fyysisen yhteyden katkeaminen kotimaahan tulkittiin yksioikoisesti moraalisen selkärangan katkeamiseksi. Pakolaiset juurettomina ihmisinä menettivät asemansa "rehellisinä kansalaisina". Vaikka myöhempi pakolaistutkimuksen kenttä eroaakin Malkin mukaan luonteeltaan selvästi sodanjälkeisestä tutkimuksesta, pakolaiset määrittyvät myös uudemmassa kirjallisuudessa ongelmaksi samaan tapaan kuin varhaisemmissa teksteissä. Ongelma paikannetaan pakolaisiksi kategorisoitujen ihmisten ruumiisiin ja mieliin, eikä esimerkiksi niihin poliittisiin olosuhteisiin, jotka tuottavat pakolaisuutta.

Teoksen kolmas artikkeli "Pakolaiset ja maanpakolaisuus: 'Pakolaistutkimuksesta' asioiden kansalliseen järjestykseen" on katsausartikkeli, joka esittelee kriittisesti pakolaisuutta käsittelevää kirjallisuutta ja tutkimusta. Se on alun perin ilmestynyt vuonna 
1995, joten sen jälkeen on ilmestynyt runsaasti aiheeseen liittyvää tutkimusta. Teoksen toimitus onkin lisännyt tekstiin alaviitteitä, jotka johdattavat lukijan uudemman sekä myös suomalaisen tutkimuksen pariin. Malkin artikkelia voidaankin pitää yhtenä avauksena kriittiseen pakolaisuuden tutkimukseen ja sen kehittymiseen nykyiseen muotoonsa.

Artikkelissa Malkki jatkaa siitä, miten pakolaisesta ja pakolaisuudesta on tullut tiedon ja politiikan kohteita. Hän lähestyy ilmiötä historiallisesta näkökulmasta tarkastelemalla Euroopassa toisen maailmansodan jälkimainingeissa muotoutuneita pakolaisuuden määritelmiä ja pakolaisuuden hallinnointia sekä niitä diskursiivisia ja institutionaalisia konteksteja, joilla pakolaisuutta on muotoiltu. Tällaisilla konteksteilla Malkki tarkoittaa kansainvälistä oikeutta, kansainvälisen politiikan tutkimusta, YK:n ja muiden kansainvälisten pakolaisjärjestöjen tuottamia dokumentteja, kehitystutkimusta sekä kirjallisuuden tutkimusta.

Malkki lähtee siitä ajatuksesta, että pakolaiset eivät muodosta itsemäärittyvää ja luonnollista akateemisen tiedon kenttää. Hän muistuttaa, että meidän ei pidä olettaa, että pakolaisstatus itsessään tuottaisi yleistettävän psykologisen tilan. Malkki myös osoittaa, että pakolaista ei ole aina tunnettu erityisenä sosiaalisena kategoriana, vaan sen synty ajoittuu juuri toisesta maailmansodasta toipuvaan Eurooppaan, jolloin standardoitiin sellaiset keskeiset tekniikat laajamittaisen pakolaisuuden hallitsemiseksi kuten pakolaisleirit. Tuolloin pakolaisia ei suinkaan nähty kansainvälisenä humanitaarisena ongelmana, vaan heidät luokiteltiin ennen kaikkea sotilaalliseksi ongelmaksi. Sotilasleirin perusmalli omaksuttiin 1940-luvulla osaksi muun muassa pakolaisleirien tilaratkaisuja ja kurikäytäntöjä. Vuonna 1951 perustetun YK:n pakolaisasiain päävaltuutetun (UNHCR) sekä Geneven pakolaissopimuksen myötä pakolaiset alettiin kuitenkin nähdä ensisijaisesti globaalina sosiaalisena ja humanitaarisena ongelmana. Malkki kiinnittää huomiota siihen, millainen tutkijoiden rooli on tiedontuottamisessa: sillä, miten pakolaisuutta tuotetaan, on todellisia vaikutuksia myös siihen, millaisen muodon avustustoimenpiteet pakolaiskriisien yhteydessä saavat.

\section{ETNOGRAFIA, TUNTEET JA IMPROVISOINTI}

Kirjan kuudes artikkeli "Perinteet ja improvisointi etnografisessa tutkimuksessa" on ilmestynyt alun perin loppulukuna teoksessa Improvising Theory: Process and Temporality in Ethnographic Fieldwork (2007), jonka Liisa Malkki kirjoitti yhdessä politiikantutkija Allaine Cerwonkan kanssa. Kirja pohjautuu Cerwonkan ja Malkin 1994-1995 sähköpostitse käytyyn kirjeenvaihtoon. Kirjeissä he keskustelevat muun muassa etnografisen tutkimuksen tekemiseen liittyvistä kysymyksistä.

Kyseisessä artikkelissa Malkki käy tieteenfilosofista keskustelua etnografisen tiedon luonteesta suhteessa muilla tavoin tuotettuun tutkimustietoon. Malkki pyrkii avaamaan etnografista tiedontuottamisen tapaa sekä kenttätyön itsestäänselvyyksiä, joita ei useinkaan ole kirjattu metodologisiin oppaisiin tai edes valmiisiin tutkimuksiin. Tätä keskustelua käydessään hän nojautuu pitkälti vanhempaan antropologiseen kirjallisuuteen (esim. Leach 1967), jossa määrällisten ja laadullisten menetelmien vastakkainasettelu 
on ollut hyvin ilmeistä, mutta jolloin etnografista menetelmää on jouduttu puolustamaan ja perustelemaan. Malkki on toki tietoinen tästä vastakkainasettelusta, ja hän on tekstissään pehmentänyt esimerkiksi Edmund Leachin lausumia. Vaikka kyseisen esseen tarkoituksena on ollut ennen kaikkea tarkastella etnografisen tiedon erityisluonnetta, jäin kuitenkin sivujuonteena kaipaamaan toimituksen lisäystä viimeaikaisemmasta metodisesta keskustelusta, joka on moniäänisempää ja jossain määrin myös kvalitatiivisten ja kvantitatiivisten menetelmien vastakkainasettelua purkavaa ja niitä yhdistelemään pyrkivää (esimerkiksi mixed methods).

Esseen parasta antia on erityisesti sen toinen puoli, jossa Malkki käsittelee etnografisen tutkimuksen tekemistä: mitä kentällä oltaessa oikeastaan tapahtuu, mitä etnografi tekee ja miten. Hän pohtii muun muassa tunteiden ja improvisaation merkitystä etnografisessa tutkimusprosessissa. Tunteiden, kuten pelon merkityksestä kenttätyöprosessissa (josta kirjoitetaan ylipäätään liian vähän) Malkki kirjoittaa osuvasti:

ne nostattivat mieleeni ja pakottivat käsittelemään tärkeitä eettisiä kysymyksiä, jotka liittyivät tutkittavien anonymiteettiin, luottamuksellisuuteen, informanttien suostumukseen osallistua tutkimukseeni ja niiden ihmisten turvallisuuteen, joiden parissa olin ja tein työtäni. Olisi ollut hyvin vaikea erottaa toisistaan tunteet ja ajattelu. Niiden erottaminen olisi ollut suorastaan analyyttisesti haitallisia. (s. 194.)

Malkki myös esittää improvisaatiolla olevan keskeisen roolin kenttätyössä. Kyse ei ole kuitenkaan mielivaltaisesta toiminnasta tai valmistautumattomuudesta kenttätöihin. Osatakseen improvisoida hyvin, etnografin on Malkin mukaan täytynyt käyttää lukemattomia tunteja harjoitteluun ja kenttätyöhön valmistautumiseen. Improvisaatio pohjautuu siis aina tiettyihin sääntöihin, ja sen on perustuttava tutkijan jo aiemmin opittuun ja omaksuttuun teoreettiseen, käsitteelliseen ja metodologiseen ymmärrykseen.

\section{MUUTTOLIIKKEEN JA PAKOLAISUUDEN TUTKIMUKSESTA}

Liisa Malkin tekstien käännöstyöstä vastanneet Laura Huttunen, Mari Korpela, Anna Rastas, Arvi Pihlman, Matias Helinko ja Mirkka Helkkula ovat tehneet huolellista työtä. Käännösratkaisut ovat pohdittuja, ja ne ovat myös nähtävillä johdantoluvun lisäksi läpi koko kirjan: vaikeasti suomen kielelle kääntyvien sanojen alkuperäinen englanninkielinen muoto on lukijaystävällisesti jätetty sulkuihin suomennoksen yhteyteen. Yksittäisiä, muutamia kirjoitusvirheitä lukuun ottamatta teksti on sujuvaa ja helppolukuista, eikä huomio lukiessa kiinnity itse asiasisällöstä liiaksi kieleen.

Artikkelit toimivat hyvin kokonaisuutena, niissä on varsin vähän päällekkäisyyttä ja toistoa siitä huolimatta, että ne pohjaavat samaan empiiriseen aineistoon. Kukin artikkeli tuo jotain uutta vaihtamalla näkö- ja tulokulmaa esimerkiksi pakolaisuusteemaan kytkeytyen. Yksiin kansiin koottuna kirjoitukset osallistuvat useisiin edelleen ajankohtaisiin muuttoliikettä ja maahanmuuttoa käsitteleviin niin teoreettisiin kuin 
Anne Häkkinen: Näkökulmia pakolaisuuden, paikan ja identiteetin tutkimukseen

metodologisiinkin keskusteluihin. Vaikka monet kirjaan valikoiduista teksteistä ovat ilmestyneet vuosikymmen, vanhimmat jopa kaksi vuosikymmentä sitten, ne ovat edelleen yllättävän ajankohtaisia kyseenalaistaessaan vakiintuneita tapojamme (niin tieteessä kuin arkiajattelussa) mieltää paikan, kulttuurin ja kuulumisen kytköksiä. Tämän vuoksi kirja on suositeltavaa luettavaa kaikille teoksen teemoista sekä etnografisesta tutkimuksesta kiinnostuneille yli tieteenalarajojen. Helppotajuisuutensa vuoksi se soveltuu erinomaisesti myös perustutkinto-opiskelijoille.

\section{KirJallisuUS}

CERWONKA, ALLAINE \& MALKKI LIISA H. 2007: Improvising theory: process and temporality in ethnographic fieldwork. Chicago : University of Chicago Press.

LEACH, EDMUND 1967: An Anthropologist's Reflections on a Social Survey. Jongmans, Douwe G. \& Gutkind, Peter C. W. (eds.), Anthropologists in the Field. Assen: Van Gorcum.

MALKKI, LIISA 1995: Purity and Exile: Violence, Memory and National Cosmology among Hutu Refugees in Tanzania. Chicago: University of Chicago Press.

Filosofian maisteri Anne Häkkinen toimii etnologian tohtorikoulutettavana historian ja etnologian laitoksella Jyväskylän yliopistossa. 